\title{
Insult or prejudice: \\ a study on the racial prejudice expression in football
}

\author{
Andreza Silene Silva Ferreira \\ Eldo Lima Leite \\ Aíla Souza Muniz \\ Universidade Federal da Paraíba, PB, Brasil \\ José Roniere Morais Batista \\ Universidade Federal de Campina Grande, PB, Brasil \\ Ana Raquel Rosas Torres \\ Universidade Federal da Paraíba, PB, Brasil \\ José Luis Álvaro Estramiana \\ Universidad Complutense de Madrid, Espanha
}

\begin{abstract}
This study aimed at analyzing the extent to which racial prejudice in football mediates the relationship between the use of verbal aggressions and compliance positioning that deny the existence of racial prejudice in football. Participants were 295 university students from Paraíba (Brazil), aged between 15 and 61 years $(\mathrm{M}=21, \mathrm{DP}=6,01)$, being 109 males and 185 females. The results indicated that racial prejudice totally mediated the relationship between verbal aggressions and compliance with legal actions. Thus, verbal attacks are not merely the expression of negative attitudes directed towards the rival team but, to the extend that they are significantly associated with prejudice, they become a powerful form of legitimation of racial prejudice in denying its existence.
\end{abstract}

Keywords: racial prejudice; verbal aggression; racism in football.

\section{Xingamento ou preconceito: um estudo sobre a expressão do preconceito racial no futebol \\ Resumo}

Este trabalho teve como objetivo analisar em que medida o preconceito racial no futebol medeia a relação entre o uso de agressões verbais e a concordância com posicionamentos que negam a existência do preconceito racial no futebol. Participaram desta pesquisa 295 estudantes universitários da Paraíba, com idades entre 15 e 61 anos $(M=21, D P=6,01)$ sendo 109 do sexo masculino e 185 do sexo feminino. Os resultados indicaram que a variável "preconceito racial" mediou totalmente a relação entre a agressão verbal e a concordância com as ações judiciais. Assim, as agressões verbais não seriam apenas manifestações de atitudes negativas direcionadas ao time rival, mas ao estarem associadas, de maneira significativa, com o preconceito, convertem-se em uma poderosa forma de legitimação do preconceito racial ao negar sua existência.

Palavras-chave: preconceito racial; agressão verbal; racismo no futebol.

\section{Insulto o prejudicio: un estudio sobre la expresion racial del prejuicio en el futbol}

\section{Resumen}

Este trabajo tuvo como objetivo analizar en qué medida el prejuicio racial en el fútbol media la relación entre la manifestación de agresiones verbales y el grado de acuerdo con posicionamientos que niegan la existencia de prejuicio racial en el fútbol. Participaron en esta investigación 295 estudiantes universitarios de Paraíba, con edades comprendidas entre los 15 y los 61 años (M=21, $\mathrm{DS}=6,01)$ de los cuales 109 eran hombres y 185 mujeres. Los resultados indican que la variable "prejuicio racial" medió totalmente la relación entre la agresión verbal y el acuerdo con las acciones judiciales. Las agresiones verbales no son meras manifestaciones de actitudes negativas frente al equipo rival, sino que están asociadas de manera significativa con el prejuicio lo que explica que en presencia de éste se conviertan en una poderosa forma de legitimación del prejuicio al negar su existencia.

Palabras clave: prejuicio racial; agresión verbal; racismo en el fútbol. 


\section{Introduction}

Soccer is considered the greatest social phenomenon of Brazil (Guterman, 2013), seen as a true "national passion". Its fans are distributed in all walks of life. Thus, soccer would reflect the diversity of social and cultural manifestations of our society. In this sense, soccer would transcend the game of sport and encompass the symbolic interactions developed within the heart of Brazilian society.

When observing soccer from this point of view, it is recognized that its organization can represent the economic, political, and racial dynamics of the society in which it is expressed (Guterman, 2013; Rodrigues, 2013). These dynamics would include the relationships between groups and would mark the symbolic positions that each group occupies in society. Thus, attitudes, values, representations, social norms and behaviors would be important elements of the Brazilian soccer arena. In this article we are interested, specifically, in the interracial and potentially prejudiced relationships that exist in the context of Brazilian soccer.

But how can one talk of racial prejudice in a society that considers itself a racial democracy? In Brazil, racial miscegenation has characterized the formation of the Brazilian people and, in a way, has also supported belief in the Myth of racial Democracy, indicating the absence of prejudice and discrimination between Whites, Blacks, and Indigenous people. This type of discourse tries to minimize the process of exclusion suffered by Blacks, denying the existence of racial differences arising out of the period of slavery (Almeida \& Rodrigues, 2015; Bartel, 2014; Camino et al., 2013; dos Santos, Neta, \& dos Santos, 2015; Gregório \& Melo, 2015).

Indeed, the myth of racial democracy draped Brazilian racism with a precocity of anti-racism norms, generating more subtle and veiled expressions of racism from early on (Fernandes, 2015; Lima \& Vala, 2004). However, one must consider that prejudiced attitudes are generated in concrete cases of discrimination (Batista, Leite, Torres \& Camino, 2014; Camino, Silva, Machado, \& Pereira, 2001; Gonzaga, 2014; Lins, Lima-Nunes, \& Camino, 2014), and as in other countries, Brazil also has cases of racial discrimination.

The initial studies in social psychology on prejudice arise in the early twentieth century, Gordon Allport being among the first to write about this topic. Allport (1954) defines prejudice as "an antipathy based on a false and inflexible generalization. It can be sensed or openly expressed. It can be directed at a group as a whole or at an individual as a member of such a group" (p. 10).
Although the definition proposed by Allport (1954) is the one that has been most widely used in the studies on this topic, authors such as, for example, Brown (2010), amplify it, stating that prejudice appears not only in the form of negative assessments and beliefs, but is deeply related to discriminatory practices toward certain social groups. Thus, prejudice forms as a group process, and as such should be comprehended in the relationships that are established between social groups, and include the power struggles and the system of beliefs about what is not socially permitted.

In this perspective, prejudice is considered to be the set of disparaging social attitudes, the expression of negative affects, the manifestation of hostile or discriminatory behavior directed at members of a group for belonging to that group. Thus, prejudice is a phenomenon that can be understood at three levels: attitudinal, emotional, and behavioral. In this sense, prejudice can manifest itself in various forms, and their expressions include various motivations that may lead to racial discrimination (Brown, 2010).

With regard to the soccer context, we have frequently seen reports that indicate the existence of racial discrimination in soccer throughout the world (Bradbury, 2013; Llopis-Goig, 2013). The report prepared in 2009 on behalf of the EU Agency for Fundamental Rights (FRA) demonstrated that racism and xenophobia are obvious problems in European Football. Various incidents from 2009 showed explicit scenes of racism and discrimination against Black players and those of other nationalities who played in Europe (Peucker, 2009). A number of studies have shown that racism has also been increasingly apparent in Brazilian soccer over the past two decades (Barradas \& Lopes, 2013; Giglio, Tonini, \& Rubio, 2014; Gregório \& Melo, 2015; Lise, Souza, Jensen, \& Capraro, 2015; Rodrigues, 2013; Santos, 2014).

However, just as occurs in other contexts (Álvaro et al., 2015; Batista et al., 2014; Camino et al., 2013; Camino et al., 2001; Fernandes, Almeida, \& Nascimento, 2008; Gonzaga, 2014), in soccer sometimes expressions of prejudice are not seen as such, but as a circumstantial product resulting from the heat of emotions. Insults, in this context, even containing overt racial prejudice, would be perceived simply as a "normal" verbal attack, since it would be acceptable to use any strategy to trash the opposing team (Bartel, 2014; Giglio et al., 2014).

So, with these ideas in view, our goal in this work was to analyze the extent to which racial prejudice in soccer mediates the relationship between the use of verbal attacks and agreement with positioning that deny the existence of racial prejudice in soccer. 
In this sense, our hypothesis is that the relationship between verbal attacks and agreement with positioning that deny the existence of prejudice is totally mediated by prejudice.

\section{Method}

\section{Sample}

The study participants were 295 students from a public university in the State of Paraiba, with ages between 15 and 61 years $(M=21, S D=6.01), 109$ males and 185 females; one participant did not respond to the questionnaire. This was a convenience sample (non-probabilistic) in which individuals, being invited, participated voluntarily.

\section{Procedures}

Participants were approached in the classroom, with the professor's permission, and asked to participate in the study. They were told about the nature of the research and the procedure for completing the questionnaire. They were informed that the research would be confidential and that the data would be statistically analyzed in the aggregate, ensuring anonymity of the participants. Upon agreeing to participate in the study, participants signed the free and informed consent form. All recommendations and ethical treatment prescribed in Resolution 466/12 of the National Health Council were followed.

\section{Instrument}

To achieve the proposed objectives, we used a questionnaire that began with a story developed from incidents that have occurred at soccer matches in which one team's fan insults a player on the opposing team with derogatory terms related to his color (e.g., monkey, stinking black, and black bastard). As a result, the fan was accused of making a racial slur, however, the case was suspended by the judge responsible, who determined that the fan had only to appear at the police station before attending a game at the soccer stadium.

Right after reading the story, participants answered questions about their sociodemographic characteristics (age and sex). Then there was an item, in 7-point Likert format, related to the use of verbal attacks in soccer (at a soccer match, influenced by the context, indicate the chance of you insulting the opposing team). This item was used as the independent variable (IV) of this study.

After this, as a measure of racial prejudice in soccer, there were four items (ex.: at a soccer game, influenced by the context, you could end up using terms about color to refer to the opposing team). These items were grouped to form a prejudice indicator $($ Alpha $=0.69)$.
This indicator was used as the mediator variable (Med) in the analyses conducted. Finally, it was asked whether the participant agreed with the suspension of the racial slur case decided by the judge (To what extent do you agree that the judge's position is justifiable?) And would the participant act the same way as the judge (If you were in the judge's place, would you act the same way?). These two items are the two dependent variables (DVs) of this study.

\section{Data analysis}

The data relating to the sociodemographic items and regression calculations were analyzed using SPSS-18 for Windows and the mediation analyses using Amos 18 software.

The mediation analyses were carried out following the step by step analysis from the procedures proposed by Baron and Kenny (1986), and the confidence interval calculation was used for the indirect effect $a b$, obtained using the bootstrapped technique according Preacher and Hayes (2004; 2008). According to Baron and Kenny (1986), there are four conditions necessary for the occurrence of mediation: 1 - the predictor variable significantly affects the mediator variable; 2 - the predictor variable significantly affects the dependent variable (DV) in the absence of the mediating variable; 3 - the mediating variable has a unique significant effect on the $\mathrm{DV}$, when the predictor variable is controlled; and 4 - the effect of the predictor variable on the DV weakens or disappears upon addition of the mediating variable. Thus, the mediation model being tested in this study (Figure 1) is that verbal abuse predicts agreement with the judge. However, this relationship is mediated by the existence of racial prejudice in soccer. This means that when the mediator variable is included in the equation, the relationship between verbal abuse and agreement with the judge will be weakened (partial mediation) or disappear (complete mediation).

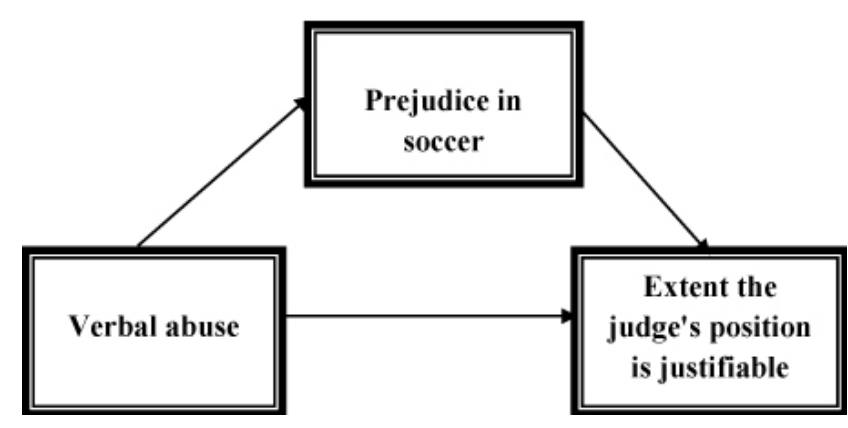

Figure 1. Mediation model of the relationship between verbal abuse (IV), the existence of racial prejudice in soccer (Med), and agreement with the judge (DV). 


\section{Results}

Initially, following the indications of Baron and Kenny (1986), a regression analysis was done in order to verify how verbal abuse is related to agreement on the extent to which the judge's position is considered justifiable (Table 1).

TABLE 1

Linear Regression of the Extent to Which the Judge's Position is Considered Justifiable, in Relation to Verbal Abuse in Soccer

\begin{tabular}{lcccc}
\hline \multicolumn{4}{c}{ Extent to which the judge's position is justifiable } \\
\hline \multicolumn{1}{c}{ Predictor } & $B$ & Beta & $T$ & $p$ \\
\hline Verbal abuse & .20 & .22 & 3.89 & $<.001$ \\
Regression coefficient & $\mathrm{R}=0.22 ; \mathrm{R}^{2}=.04$ & \\
Explained variance & $\mathrm{R}^{2}$ adjusted $=.04$ & \\
Statistical test & $\mathrm{F}(1,293)=15.162 ; p<.001$ \\
\hline
\end{tabular}

The results showed that the higher the level of verbal abuse in soccer, the more the judge's position is considered justifiable. Next, a regression was run with the extent the judge's position is considered justifiable as the dependent variable and the existence of racial prejudice as an independent variable. There was a significant association between the predictor and the dependent variable, which can be seen in Table 2.

TABLE 2

Linear Regression of the Extent to Which the Judge's Position is Considered Justifiable, in Relation to the Existence of Racial Prejudice in Soccer

\begin{tabular}{lcccc}
\hline \multicolumn{5}{c}{ Extent to which the judge's position is justifiable } \\
\hline \multicolumn{1}{c}{ Predictor } & $B$ & Beta & $T$ & $p$ \\
\hline Prejudice in soccer & .79 & .79 & 10.14 & $<.001$ \\
Regression coefficient & \multicolumn{2}{c}{$=.51 ; \mathrm{R}^{2}=.26$} \\
Explained variance & $\mathrm{R}^{2}$ adjusted $=.25$ \\
Statistical test & $\mathrm{F}(1,293)=102.90 ; p<.001$ \\
\hline
\end{tabular}

The results showed that the greater the prejudice, the more the judge's position is considered justifiable. In order to verify the true contribution of verbal abuse in the extent to which the judge's position is considered justifiable, confronted with a case of racial prejudice in soccer, the third multiple regression analysis was run, having verbal abuse and the existence of racial prejudice as predictor variables, and the extent the judge's position is considered justifiable as the dependent variable (Table 3).
TABLE 3

Multiple Regression of the Extent the Judge's Position is Considered Justifiable, as a Function of Verbal Abuse and the Existence of Racial Prejudice in Soccer

\begin{tabular}{lcccc}
\hline \multicolumn{5}{c}{ Extent to which the judge's position is justifiable } \\
\hline \multicolumn{1}{c}{ Predictors } & $B$ & Beta & $T$ & $p$ \\
\hline Verbal abuse & .029 & .032 & .58 & $<.561$ \\
Prejudice in soccer & .78 & .50 & 9.142 & $<.001$ \\
Regression coefficient & \multicolumn{5}{c}{$=.51 ; \mathrm{R}^{2}=.26$} \\
Explained variance & $\mathrm{R}^{2}$ adjusted $=.25$ \\
Statistical test & $\mathrm{F}(2,292)=51.507 ; p<.001$ \\
\hline
\end{tabular}

Aiming for the reduction of the principal effect of verbal abuse on the judge's position, mediation analyses (Figure 2) were conducted, with verbal abuse as the predictor variable, the existence of racial prejudice as mediator variable, and the extent the judge's position is considered justifiable as the dependent variable.
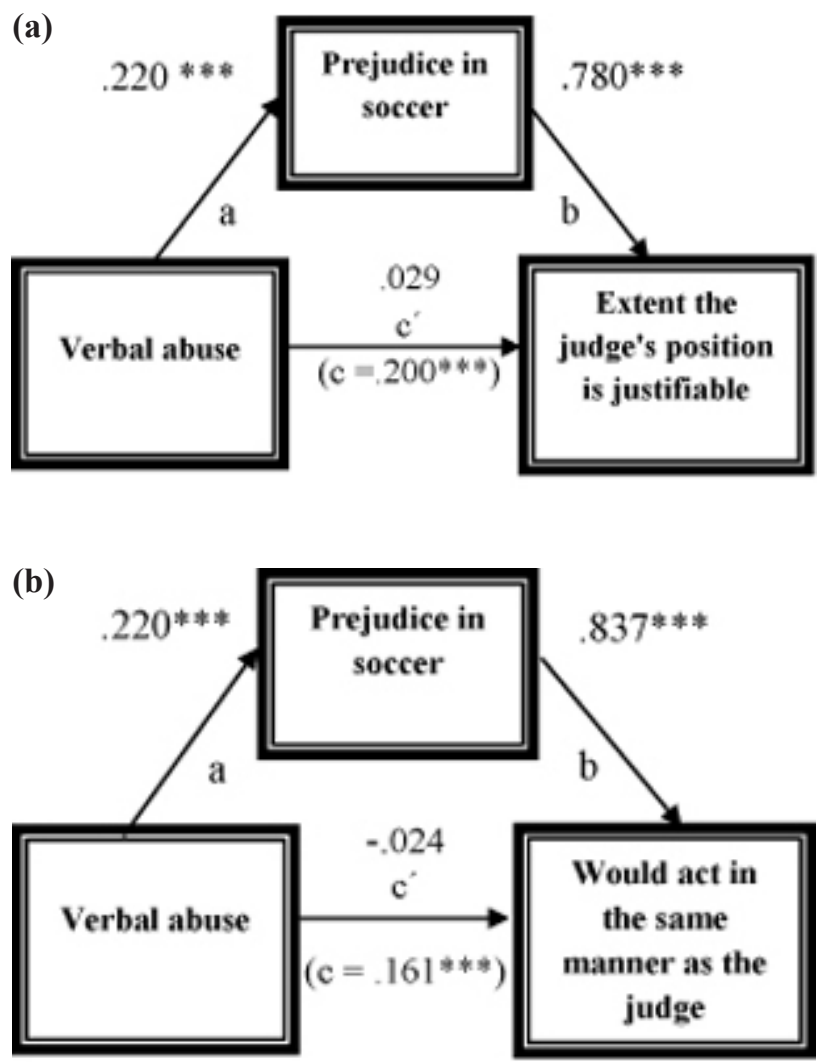

Figure 2. (a) Analysis of the mediation of verbal abuse as a predictor, the existence of racial prejudice in soccer as a mediator, and the extent the judge's position is considered justifiable as the dependent variable; (b) Analysis of the mediation of verbal abuse as a predictor, the existence of racial prejudice in soccer as a mediator, and the probability the participant would act in the same manner if he/she were in the judge's place, as the dependent variable. 
As seen in Figure 2, the effect of verbal abuse on the extent the judge's position is considered justifiable was mediated by the existence of racial prejudice (Sobel test, $\mathrm{Z}=5.78795 ; p<.001$ ). The total effect of verbal abuse on the extent the judge's position is considered justifiable was significant, $\mathrm{c}=.200$, $p<.001, \mathrm{~T}(293)=3.894, p<.001$; and also significantly predicted the mediating variable, $\mathrm{a}=.220, p<.001$, $\mathrm{T}(293)=7.076, p<.001$. The existence of racial prejudice variable significantly predicted the extent the judge's position is considered justifiable, variable $\mathrm{b}=.780, p<.001, \mathrm{~T}(293)=10.144, p<.001$. The direct effect of abuse on the extent the judge's position is considered justifiable, controlling for the effect of prejudice, was $\mathrm{c}^{\prime}=.029, p=.561, \mathrm{~T}(293)=.582, p<.561$.

The bootstrapped procedure was performed to determine the significance of the indirect effect $a b$, at a value of .05 , in which resampling with replacement was done 2000 times, with bias-corrected and accelerated confidence adjustments. At the $95 \%$ significance level, a CI was obtained with an interval between .118 and .237 . Thus, prejudice completely mediated the relationship between verbal abuse and the extent the judge's position is considered justifiable.

Following the same steps, the intent was to verify how verbal abuse in soccer is related to the probability of the participant acting in the same manner if he/she were in the judge's place, and how that relationship is affected by the existence of racial prejudice in soccer. A positive association was observed between verbal abuse in the context of soccer and the probability of the participant acting in the same manner as the judge, upon removal of the racial slur accusation (Table 4).

TABLE 4

Linear Regression of the Probability of the Participant Acting in the Same Manner if he/she Were in the Judge's Place, as a Function of Verbal Abuse in Soccer

\begin{tabular}{|c|c|c|c|c|}
\hline \multicolumn{5}{|c|}{ Would act in the same manner as the judge } \\
\hline Predictor & $B$ & Beta & $T$ & $p$ \\
\hline Verbal abuse & .16 & .17 & 3.09 & $<.05$ \\
\hline Regression coefficient & \multicolumn{4}{|c|}{$\mathrm{R}=0.17 ; \mathrm{R}^{2}=.03$} \\
\hline Explained variance & \multicolumn{4}{|c|}{$\mathrm{R}^{2}$ adjusted $=.02$} \\
\hline Statistical test & \multicolumn{4}{|c|}{$\mathrm{F}(1,293)=9.573 ; p<.05$} \\
\hline
\end{tabular}

As before, a significant association was observed between the existence of racial prejudice in soccer and the probability of the participant acting in the same manner if in the judge's place, which can be seen in Table 4. The results showed that the greater the presence of racial prejudice in soccer, the higher the likelihood that the participants would act in the same manner as the judge.

TABLE 5

Linear Regression of the Probability of the Participant Acting in the Same Manner if he/she Were in the Judge's Place, as a Function of Prejudice Against Blacks in Soccer

\begin{tabular}{lcccc}
\hline \multicolumn{4}{c}{ Would act in the same manner as the judge } \\
\hline \multicolumn{1}{c}{ Predictor } & $B$ & Beta & $T$ & $p$ \\
\hline Prejudice in soccer & .82 & .52 & 10.54 & $<.001$ \\
Regression coefficient & \multicolumn{2}{c}{$=.52 ; \mathrm{R}^{2}=.27$} \\
Explained variance & $\mathrm{R}^{2}$ adjusted $=.27$ & \\
Statistical test & $\mathrm{F}(1,293)=111.15 ; p<.001$ \\
\hline
\end{tabular}

In order to verify the true contribution of verbal abuse in the probability of the participant acting in the same way as the judge, considering a case of racial prejudice in soccer, the third multiple regression analysis was run, having verbal abuse and the existence the racial prejudice as predictor variables, and the probability of the participant acting in the same way as the judge as the dependent variable.

TABLE 6

Multiple Regression of the Probability of the Participant Acting in the Same Manner as the Judge, as a Function of Verbal Abuse and the Existence of Racial Prejudice in Soccer

\begin{tabular}{lcccc}
\hline \multicolumn{5}{c}{ Would act in the same manner as the judge } \\
\hline \multicolumn{1}{c}{ Predictors } & $B$ & Beta & $T$ & $p$ \\
\hline Verbal abuse & -.02 & -.02 & -.49 & $<.626$ \\
Prejudice in soccer & .84 & .53 & 9.92 & $<.001$ \\
Regression coefficient & \multicolumn{6}{c}{$=.52 ; \mathrm{R}^{2}=.28$} \\
Explained variance & $\mathrm{R}^{2}$ adjusted $=.27$ \\
Statistical test & $\mathrm{F}(2,292)=55.553 ; p<.001$ \\
\hline
\end{tabular}

The second mediation (Figure 2), in the same way as the previous mediation, had verbal abuse as a predictor variable, the existence of racial prejudice in soccer as a mediator variable, and changed only the dependent variable, which in this case is the probability that the participant would do the same if he/she were in the judge's place.

It is observed that the effect of verbal aggression on the probability of the participant acting in the same manner if he/she were in the judge's place was mediated by the existence of racial prejudice (Sobel test, $Z=5.86606 ; p<.001)$. The total effect of verbal abuse on the probability of the participant acting in the same manner if he/she were in the judge's place 
was significant, $\mathrm{c}=.161, p<.002, \mathrm{~T}(293)=10.62$, $p<.001$; and also significantly predicted the mediating variable, $\mathrm{a}=.220, p<.001, \mathrm{~T}(293)=10.701, p<.001$. The prejudice in soccer variable significantly predicted the probability of the participant acting in the same manner if he/she were in the judge's place, $b=.837$, $p<.001, \mathrm{~T}(293)=10.543, p<0.001$. The direct effect of verbal abuse on the probability of the participant acting in the same manner if he/she were in the judge's place, controlling for the effect of the existence of racial prejudice, was $\mathrm{c}^{\prime}=-.024, p=.626, \mathrm{~T}(293)=-.488$, $p<.626$.

The bootstrapped procedure was performed to determine the significance of the indirect effect $\mathrm{ab}$, at a value of .05 , in which resampling with replacement was done 2000 times, with bias-corrected and accelerated confidence adjustments. At the 95\% significance level, a CI was obtained with an interval between .053 and .273. Thus, the existence of racial prejudice completely mediated the relationship between verbal abuse and the probability of the participant acting in the same manner if he/she were in the judge's place.

\section{Discussion and Conclusions}

Taken together, the results indicate that verbal abuse predicts both the agreement with the position of the judge in dropping the charges of racial slur and the probability of the participant acting in the same way as the judge. However, this prediction only occurs when the existence of racial bias is presented. In other words, verbal attacks in the context of soccer imply something more than the mere expression of negative attitudes and emotions against the opposing team, because, to the extent they are associated with prejudice, they legitimize racist attitudes. This result is important because, in general, Brazilians deny they are prejudiced (Batista et al., 2014; Camino et al., 2001; Nunes, 2014; Santos, 2014). Thus, the soccer context would be appropriate for studying the existence of racial prejudice as well as its justification. Verbal attacks in which there is explicit racist content (e.g., monkey, stinking Black, etc.) are becoming increasingly common at soccer fields worldwide. What the study shows clearly is how this context leads not only to the manifestation of verbal attacks, but that they are linked to prejudice and its legitimacy. On the other hand, these results also indicate that, when analyzed more subtly, racial prejudice shows its ominous power in the context of soccer.

Various studies have shown that because of the constant expressions of verbal abuse in the soccer context, the use of expressions with color-related terms tends to be seen as merely a verbal assault devoid of prejudicial attitudes (Barradas \& Lopes, 2013; Bartel, 2014; Cervi, 2014; Giglio et al., 2014). According to Cabecinhas (2008), the use of insults and offensive language is intended to demonstrate the superiority of one group over the other. This idea supports the view of Camino et al. (2001) in which prejudice arises from the organization of power relations between the groups, in which the ideological representations justify the expression of disparaging attitudes and discriminatory behavior.

Along the same lines, Cervi (2014) states that, in the soccer context, jokes can also hide forms of intolerance, pointing out that laughter would be a way to discredit the victim, since jokes should not be taken seriously. Thus, the use of some terms, jokes, and playful phrases in soccer would be aimed at degrading the minority group. In the case of Black players, this would occur through the use of terms referring to skin color and to hair.

For Giglio et al. (2014), the manifestations of racial prejudice in the context of soccer reflect the racist structure of our society. For these authors, it is at the time of the dispute and by means of the competition that racial prejudice manifests itself unequivocally, because the social norms that preclude open expressions of racial prejudice would not be enough to prevent manifestations of this nature. This, in our view, is what happens in our results.

Finally, we consider that the sample composed only of college students could constitute a limitation of this work. Thus, future studies could be conducted with the fan associations of the soccer teams, since news about the violence between these groups is frequent in national and international media. Another aspect that we consider important for future studies regards the inclusion of instruments concerning social norms, following the Justified Discrimination Model, proposed by Pereira and Vala (2010), and adherence to value systems, as investigated by Álvaro et al. (2015). 


\section{Referências}

Allport, G. W. (1954). The nature of prejudice. Cambridge, MA: Addison-Wesley.

Almeida, M. M. \& Rodrigues, F. X. F. (2015). O mito da democracia racial, racismo e futebol: um debate sociológico. Novos Rumos Sociológicos, 3(3).

Álvaro, J. L., Morais, T., Torres, A. R. R., Pereira, C. R., Garrido, A., \& Camino, L. (2015). The Role of Values in Attitudes towards Violence: Discrimination against Moroccans and Romanian Gypsies in Spain. The Spanish Journal of Psychology, 18, E63-12. https://doi.org/10.1017/sjp.2015.65

Baron, R. M. \& Kenny, D. A. (1986). The moderator-mediator variable distinction in social psychological research: Conceptual, strategic, and statistical considerations. Journal of Personality and Social Psychology, 51, 1173-1182. https://doi.org/10.1037//0022-3514.51.6.1173

Barradas, M. S. S. \& Lopes, O. G. (2013). Dribladores: passes e impasses do racismo no futebol carioca. Mnemosine, 9(1), 245-263.

Bartel, C. E. (2014). Manifestações de Racismo e de Intolerância no Brasil Contemporâneo. História Unicap, 1(1), 104-118.

Batista, J. R. M., Leite, E. L., Torres, A. R. R., \& Camino, L. (2014). Negros e Nordestinos: similaridades nos estereótipos raciais e regionais. Psicologia Politica, 14(30), 325-345.

Bradbury, S. (2013). Institutional racism, whiteness and the under-representation of minorities in leadership positions in football in Europe. Soccer \& Society, 14(3), 296-314. https://doi.org/10.1080/14660970.2013.801262

Brown, R. J. (2010). Prejudice: its social psychology. Malden, Massachusetts, USA: Blackwell Publishers Inc.

Cabecinhas, R. (2008). Racismo e Xenofobia: a actualidade de velha questão. Comunicação e Cidadania, 2, 1886-8975. http://hdl.handle.net/1822/9639

Camino, L., Álvaro, J. L., Torres, A. R. R., Garrido, A., Morais, T., \& Barbosa, J. (2013). Explaining Social Discrimination: Racism in Braziland Xenophobia in Spain. Spanish Journal of Psychology, 16, e73, 1-13. https://doi.org/10.1017/ sjp.2013.65

Camino, L., Da Silva, P., Machado, A., \& Pereira, C. (2001). A face oculta do racismo no Brasil: uma análise psicossociológica. Revista Psicologia Política, 1(1), 13-36.

Cervi, T. de A. N. (2014). Intolerância e racismo no futebol: a racialização do outro. ComCiência, 159, Campinas.

Dos Santos, E. D., Neta, M. D. C. M. A., \& dos Santos, R. D. (2015). A questão das relações étnicas no Brasil: (não) somos racistas?! Cadernos Imbondeiro, 3(2).

Fernandes, F. (2015). O negro no mundo dos brancos. [S.1.]: Global Editora.

Fernandes, S. C. S., Almeida, S. S. M. \& Nascimento, C. B. S. (2008). Análise do preconceito racial em uma amostra de crianças brancas de 5 a 8 anos de idade. Psico, Porto Alegre, PUCRS, 39(4), 441-447.

Giglio, S. S., Tonini, M. D., \& Rubio, K. (2014). "Do céu ao inferno": a história de Baiano no Boca Juniors e os racismos no futebol. Projeto História. Revista do Programa de Estudos Pós-Graduados de História, 49. e-ISSN 2176-2767; ISSN 0102-4442.

Gonzaga, Y. M. (2014). Relações raciais em uma Universidade Pública Federal Brasileira: um campo em aberto.

Gregório, F. \& Melo, B. M. (2015). Preconceito racial no esporte nacional. Esporte e Sociedade, 24, 1-31.

Guterman, M. (2013). O futebol explica o Brasil: Uma história da maior expressão popular do país. São Paulo: Contexto.

Lima, M. O. \& Vala, J. (2004). As novas formas de expressão do preconceito e do racismo. Estudos de Psicologia, 9 , 401-411. https://doi.org/10.1590/S1413-294X2004000300002

Lins, S. L. B., de Lima-Nunes, A. V., \& Camino, L. (2014). O papel dos valores sociais e variáveis psicossociais no preconceito racial brasileiro. Psicologia \& Sociedade, 26(1), 12. https://doi.org/10.1590/S0102-718220140001 00011

Lise, R. S., Souza, M. T. O., Jensen, L., \& Capraro, A. M. (2015). O caso Tinga: analisando (mais) um episódio de racismo no futebol sul-americano. Pensar a Prática, 18(4). https://doi.org/10.5216/rpp.v18i4.32123.

Llopis-Goig, R. (2013). Racism, xenophobia and intolerance in Spanish football: evolution and responses from the government and the civil society. Soccer \& Society, 14(2), 262-276. https://doi.org/10.1080/14660970.2013. 776461

Nunes, S. D. S. (2014). Racismo contra negros: sutileza e persistência. Revista Psicologia Politica, 14(29), 101-121.

Pereira, C. R. \& Vala, J. (2010). Do preconceito à discriminação justificada. In-Mind_Português, 1, 1-13.

Peucker, M. (2009). Racism, xenophobia and structural discrimination in sports. European forum for migration studies (efms). Bamberg. https://doi.org/10.1007/978-3-531-91692-7_11

Preacher, K. J. \& Hayes, A. F. (2004). SPSS and SAS procedures for estimating indirect effects in simple mediation models. Behavior Research Methods, Instruments, and Computers, 36, 717-731. https://doi.org/10.3758/BF03206553

Preacher, K. J. \& Hayes, A. F. (2008). Asymptotic and resampling strategies for assessing and comparing indirect effects in multiple mediator models. Behavior Research Methods, 40, 879-891. https://doi.org/10.3758/BRM.40.3.879 
Rodrigues, K. De C. (2013). Esporte e folkcomunicação: o futebol mostra a brasilidade. RIF, Ponta Grossa/PR, 11(24), 66-81.

Santos, T. C. (2014). A Campanha \#somostodosmacacos de Neymar: uma reflexão sobre o racismo no futebol. São Paulo: Congresso Internacional de comunicação e consumo.

Autores:

Andreza Silene Silva Ferreira - Mestre, Universidade Federal da Paraíba.

Eldo Lima Leite - Mestre, Universidade Federal da Paraíba.

Aíla Souza Muniz - Graduanda, Universidade Federal da Paraíba.

José Roniere Morais Batista - Doutor, Universidade Federal de Campina Grande.

Ana Raquel Rosas Torres - Doutora, Universidade Federal da Paraíba.

José Luis Álvaro Estramiana - Doutor, Universidad Complutense de Madrid.

Endereço para correspondência:

Andreza Silene Silva Ferreira

Rua Paulo Araújo de Oliveira, 124

58064-270, João Pessoa, PB. Brasil

<andrezasilfer@oi.com.br>

Recebido em: 03.09.2016

Aceito em: 02.01.2017 